\title{
Perbandingan Algoritma Genetika dan Backpropagation pada Aplikasi Prediksi Penyakit Autoimun
}

\author{
Debi Setiawan $^{1 *}$, Ramalia Noratama Putri ${ }^{2}$, Reni Suryanita ${ }^{3}$ \\ ${ }^{1}$ Program Studi Teknik Informatika \\ STMIK Amik Riau \\ Riau \\ ${ }^{2}$ Program Studi Sistem Informasi \\ Sekolah Tinggi Ilmu Komputer Pelita Indonesia \\ Riau \\ ${ }^{3}$ Program Studi Teknik Sipil \\ Universitas Negeri Riau \\ Riau \\ *debisetiawan@stmik-amik-riau.ac.id
}

\begin{abstract}
Abstrak-Penyakit autoimun adalah penyakit yang disebabkan oleh sistem imun yang kacau. Sehingga imun pada tubuh penderita menyerang penderita itu sendiri. Penelitian di Amerika Serikat menunjukkan lebih dari 23,5 juta penduduk menderita penyakit autoimun, sumber data Departemen Kesehatan dan Layanan Kemanusiaan Amerika Serikat. Pada data SIRS Online Ditjen Pelayanan Kesehatan 2017 menunjukkan data proporsi pasien berjenis kelamin laki-laki 54,3\% dan pasien berjenis kelamin wanita $45,7 \%$. Meningkatnya penderita penyakit autoimun disebabkan sulitnya untuk mendiagnosis penyakit autoimun, karena gejala dari penyakit autoimun bervariasi. Penelitian ini membandingkan algoritma backpropagation dan algoritma genetika dalam memprediksi penyakit autoimun. Perbandingan dilakukan berdasarkan nilai accuracy, sensitifity, dan Presicion. Data yang digunakan dalam penelitian ini adalah 24 data pasien penyakit dalam. Prediksi penyakit autoimun menggunakan algoritma backpropagation memiliki nilai accuracy 0.83 , sensitifity 97\%, dan presicion 75\%. Sedangkan prediksi penyakit autoimun dengan algoritma genetika memiliki nilai accuracy 0.76 , sensitifity $81 \%$, dan presicion $75 \%$. Dari perbandingan tersebut dapat disimpulkan bahwa algoritma backpropagation memberikan prediksi penyakit autoimun lebih baik dari algoritma genetika.
\end{abstract}

Kata kunci: Prediksi, autoimun, algoritma backpropagation, algoritma genetika

\section{Pendahuluan}

Penyakit Autoimun bukanlah penyakit menular seperti Penyakit HIV/AIDS. Namun, Populasi penderita penyakit autoimun semakin meningkat. Penyakit autoimun adalah penyakit kekacauan sistem imun, sel-sel imun pada penderita penyakit autoimun akan menyerang tubuh sendiri.

Penyakit autoimun mulai diperhatikan oleh pakar kesehatan di dunia. Penelitian di Amerika Serikat menunjukkan 10 juta penduduk menderita penyakit autoimun terdapat 80 jenis. Dan sekitar $75 \%$ pasien penyakit autoimun adalah wanita [1]. Pada data SIRS Online Ditjen Pelayanan Kesehatan 2017 menunjukkan data proporsi pasien berjenis kelamin laki-laki 54,3\% dan pasien berjenis kelamin wanita $45,7 \%$. Berdasarkan data tersebut dapat disimpulkan bahwa saat ini penyakit autoimun dapat menyerang wanita pada usia produktif 15-50 tahun [2].

Perhimpunan SLE Indonesia (PESLI) melakukan penelitian terhadap 8 rumah sakit besar yang tersebar di Indonesia. Hasil penelitian tersebut adalah 10,5\% terdapat insiden kasus baru.
Tabel 1. Insiden kasus baru rumah sakit besar di Indonesia

\begin{tabular}{ll}
\hline Nama Rumah Sakit & $\begin{array}{l}\text { Insiden Kasus } \\
\text { Baru }\end{array}$ \\
\hline RS Cipto MAngunkusumo & $22.9 \%$ \\
RS Saiful Anwar Malang & $14,5 \%$ \\
RS Muhammad Husin palembang & $11,7 \%$ \\
Sardjito Yogyakarta & $10,6 \%$ \\
RS Moewardi Denpasar & $10,0 \%$ \\
RS Sanglah Denpasar & $6,6 \%$ \\
RS Kanujoso Djatiwibowo Balikpapan & $4,0 \%$ \\
RSUD Ulin Banjarmasi & $1,2 \%$ \\
\hline
\end{tabular}

Sumber : Base Data,Adult Systemic Lupus Hospital, PESLI 2017

Semakin meningkatnya penderita penyakit autoimun dan timbulnya kasus baru setiap tahun, disebabkan karena penyakit autoimun mirip dengan penyakit lain sehingga sulit didiagnosis. Gejala dari penyakit autoimun bervariasi sangat luas akibatnya diagnosis dan pengobatan menjadi sulit [1]. Gejala yang bervariasi dan tidak luas 
ini menyebabkan penderita sering berganti-ganti dokter karena diagnosis yang berbeda-beda[3].

Permasalahnya keterlambatan diagnosis mengakibatkan penderita mengalami kerusakan yang kronis pada tubuhnya. Untuk itu diperlukannya suatu aplikasi dalam melakukan prediksi penyakit autoimun untuk memudahkan dokter dalam melakukan diagnosis terhadap penderita penyakit autoimun.

Dalam bidang kesehatan algoritma backpropagation telah banyak diterapkan. Pada peneliti sebelumnya algoritma backpropagation digunakan untuk memprediksi penyakit jantung, hasil dari penelitian tersebut adalah bahwa algoritma backpropagation dapat memprediksi penyakit jantung dengan hasil yang lebih akurat, yaitu accuracy $91.45 \%$ [4]. Untuk mendiagnosis penyakit perlu ketepatan dalam mendeteksi suatu penyakit. Peneliti sebelumnya menggunakan kombinasi fuzzy tsukamoto dan algoritma genetika untuk diagnosis penyakit sapi potong. Kesimpulan pada penelitian tersebut yaitu terdapat peningkatan akurasi $3.54 \%$ setelah dilakukan optimasi dengan algoritma genetika [5].

Penerapan algoritma backpropagation dan algoritma genetika untuk prediksi sudah banyak dilakukan oleh peneliti sebelumnya. Beberapa di antaranya yaitu Implementasi JST pada prediksi Total Laba dan Rugi Komprehensif Bank Umum Konvensional dengan Backpropagation, hasil dari penelitian tersebut algoritma backpropagation dengan model aristektur 40-5-1 prediksi total laba rugi menunjukkan akurasi $80 \%$ [6]. Peneliti sebelumnya juga telah menerapkan Algoritma Genetika pada Jaringan Syaraf Tiruan untuk predikai curah hujan di Kabupaten Bandung, hasil penelitian tersebut menunjukkan akurasi diatas 70\% [7].

Pada penelitian ini peneliti melakukan perbandingan algoritma backpropagation dan algoritma genetika untuk prediksi penyakit autoimun. Peneliti sebelumnya telah melakukan perbandingan algoritma Backpropagation dengan algoritma Genetika untuk pengenalan karakter, hasil perbandingan adalah algoritma Backpropagation memiliki akurasi $84.62 \%$ dan algoritma Genetika memiliki akurasi $61.54 \%$ [8]. Penelitian sebelumnya juga pernah melakukan perbandingan algortima backpropagation dengan Support Vector Machine, hasil perbandingan menunjukkan Support Vector Machine lebih akurat dari algoritma backpropagation yaitu 100\% [9].

Perbandingan pada penelitian ini dilihat berdasarkan accuracy, sensitifity, dan presicion, sehingga didapat algoritma yang terbaik dalam memprediksi penyakit autoimun.

\section{Metode}

Rangkaian kerja dari penelitian dalam menyelesaikan masalah dapat dilihat pada Gambar 1.

\section{a. Perancangan Sistem}

Pada tahapan perancangan sistem, dilakukan perancangan terhadap dua sistem yang dibangun, yaitu sistem yang menerapkan algoritma backpropagation dan sistem yang menerapkan algoritma genetika. Data yang digunakan dalam penelitian ini adalah 24 data pasien penyakit dalam pada bulan Agustus tahun 2018 di Rumah
Sakit Arifin Achmad Provinsi Riau Kota Pekanbaru. Pasien yang berkunjung ke dokter spesialis penyakit dalam mengisi questioner yang diberikan. Tabel 2 adalah daftar pertanyaan dalam questioner prediksi penyakit autoimun.

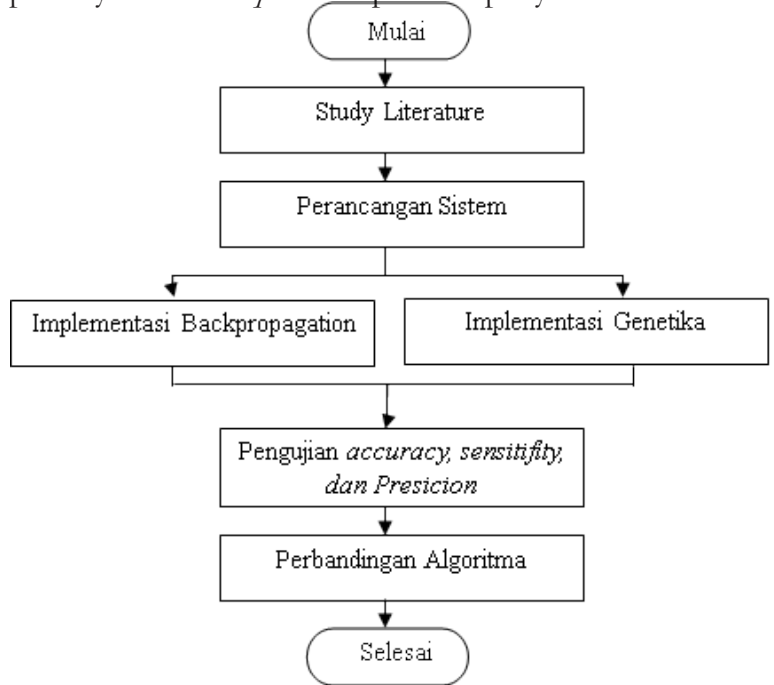

Gambar 1. Rangkaian kerja penelitian

Tabel 2. Daftar pertanyaan

\begin{tabular}{|c|c|}
\hline No & PERTANYAAN \\
\hline 1 & $\begin{array}{l}\text { Apakah beberapa hari ini bapak/ibu mengalami rasa ngilu pada } \\
\text { pegelangan sendi? }\end{array}$ \\
\hline 2 & Apakah beberapa hari ini bapak/ibu mengalami lemah pada otot? \\
\hline 3 & $\begin{array}{l}\text { Apakah beberapa hari ini bapak/ibu mudah mendapatkan } \\
\text { serangan penyakit? }\end{array}$ \\
\hline 4 & $\begin{array}{l}\text { Apakah bapak/ibu tidak tahan terhadap cuaca dingin atau sensitif } \\
\text { terhadap cuaca panas? }\end{array}$ \\
\hline 5 & Apakah bapak/ibu mengidap alergi kulit \\
\hline 6 & Apakah bapak ibu merasakan lelah berkepanjangan? \\
\hline 7 & Apakah bapak/ibu merasakan insomnia? \\
\hline 8 & $\begin{array}{l}\text { Apakah bapak ibu merasa kurang enak badan seperti demam } \\
\text { ringan? }\end{array}$ \\
\hline 9 & Seringkah ibu berkeringat di malam hari? \\
\hline 10 & $\begin{array}{l}\text { Apakah bapak ibu beberapa hari ini mengalami mati rasa di } \\
\text { tangan dan di kaki? }\end{array}$ \\
\hline 11 & $\begin{array}{l}\text { Apakah bapak/ibu ada berkunjung ke dokter dan memeriksa } \\
\text { tekanan darah? apakah tekanan darah bapak ibu rendah? }\end{array}$ \\
\hline 12 & $\begin{array}{l}\text { Apakah bapak/ibu mengalami (tremor) atau getaran atau } \\
\text { menggigil yang terjadi secara tidak sadar? }\end{array}$ \\
\hline 13 & Apakah bapak ibu sering mengalami mata kering? \\
\hline 14 & $\begin{array}{l}\text { Apakah bapak atau ibu mengalami kehilangan atau penurunan } \\
\text { berat badan yang drastis dalam beberapa bulan ini? }\end{array}$ \\
\hline 15 & Apakah bapak ibu mengalami rambut rontok? \\
\hline 16 & Apakah bapak ibu mengalami mulut kering? \\
\hline 17 & Apakah bapak/ibu merasakan napas pendek? \\
\hline 18 & $\begin{array}{l}\text { Apakah bapak/ibu merasakan rasa sakit dan karam di tulang } \\
\text { belakang? }\end{array}$ \\
\hline 19 & Apakah bapak/ibu merasakan jantung berdebar tidak wajar? \\
\hline 20 & Apakah bapak ibu merasakan pusing yang berkepanjangan? \\
\hline 21 & Apakah bapak/ibu merasakan depresi? \\
\hline 22 & Apakah bapak/ibu sulit konsentrasi dan memori terganggu? \\
\hline 23 & Apakah bapak/ibu mengalami pembengkakan pada tungkai kaki? \\
\hline 24 & $\begin{array}{l}\text { Apakah bapak/ibu mengalami pembengkakan mata kaki dan } \\
\text { wajah? }\end{array}$ \\
\hline
\end{tabular}




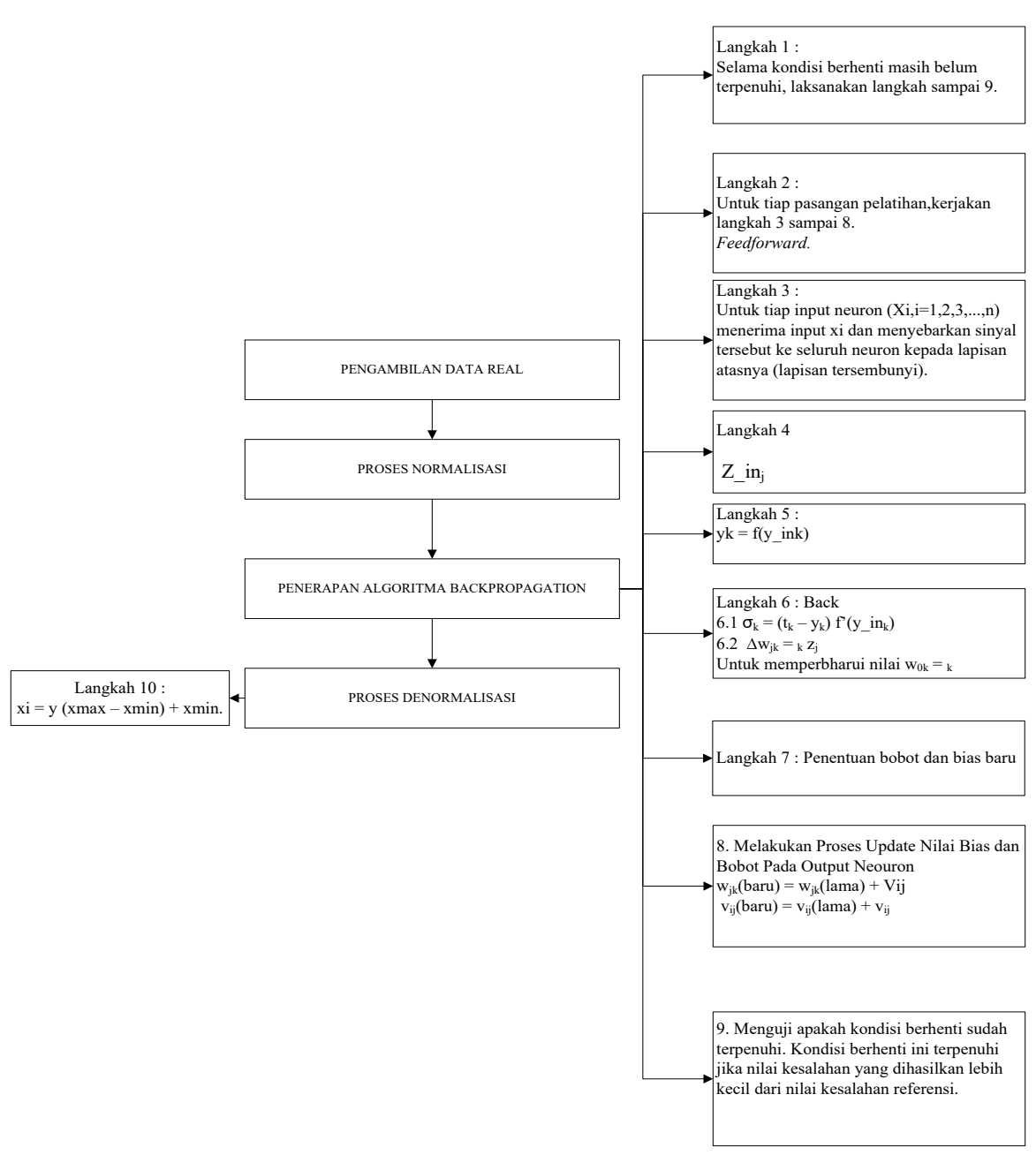

Gambar 2. Implementasi algoritma backpropagation prediksi penyakit autoimun

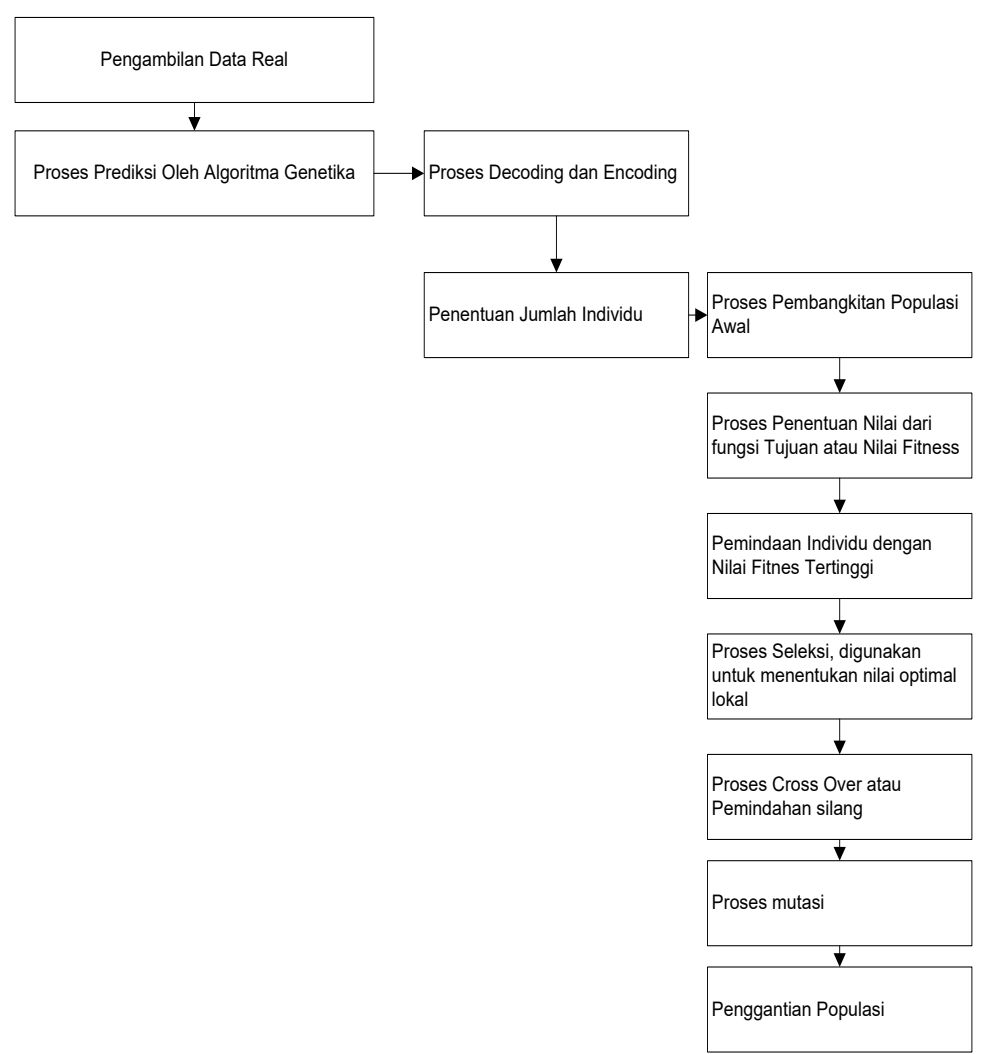

Gambar 3. Implementasi algoritma genetika prediksi penyakit autoimun 


\section{b. Algoritma Backpropagation}

Backpopagation merupakan algoritma pembelajaran yang terawasi dan biasanya dan biasanya digunakan untuk perceptron banyak lapisan untuk mengubah bobot-bobot yang terhubung dengan neuron-neuron yang ada pada lapisan tersembunyinya. Algoritma ini menggunakan error output untuk mengubah nilai bobot-bobotnya dalam arah mundur (backward). Untuk mendapatkan error ini, tahap perambatan maju (forward propagation) harus dikerjakan terlebih dahulu. Perambatan maju, neuronneuron diaktifkan dengan menggunakan fungsi aktivasi yang dapat dideferensiasikan[10].

Tahapan implementasi algoritma backpropagation dapat dilihat pada Gambar 2[11].

\section{c. Algortima Genetika}

Algoritma genetika menggunakan analogi secara langsung dari kebiasaan yang alami yaitu seleksi alam. Algoritma ini berkerja dengan sebuah populasi yang terdiri dari individu-individu, yang masing-masing individu merepresentasikan sebuah solusi yang mungkin bagi persoalan yang ada. Dalam kaitan ini, individu dilambangkan dengan dengan sebuah nilai fitness yang akan digunakan untuk mencari solusi terbaik dari persoalan yang ada [12].

Tiga aspek yang penting untuk penggunaan algoritma genetik [12]:

1. Defenisi fungsi fitness

2. Defenisi dan implementasi representasi genetik

3. Defenisi dan implementasi operasi genetik

Tahapan implementasi algoritma genetika dapat dilihat pada gambar 3:

\section{d. Pengujian Accuracy, Sensitifity, dan Presicion.}

Perbandingan dua algoritma harus memiliki alat ukur yang sama sehingga hasil perbandingan adalah algoritma yang terbaik [13]. Pada tahapan ini pengujian dilakukan dengan menghitung nilai Accuracy, Sensitifity, dan Presicion.

Accuracy adalah perhitungan jumlah proporsi prediksi yang benar[14]. Accuracy dirumuskan dalam persaman (1).
Accuracy $=\frac{T P+T N}{T P+F P+T N+F N}$

Sensitifity adalah perhitungan jumlah proporsi kasus positif yang terindentifikasi benar. Sensitifity dirumuskan dalam persamaan (2).

Sensitifity $=\frac{T P}{T P+F N}$

Presicion adalah perhitungan perkiraan jumlah proporsi kasus positif yang benar. Presicion dirumuskan dalam persamaan (3).

Presicion $=\frac{T P}{T P+F P}$

Keterangan :

TP : True Positive

TN : True Negative

FP : False Positive

FN : False Negative

\section{e. Perbandingan Algoritma}

Tahapan ini peneliti melakukan perbandingan Algoritma Backpropagation dan algoritma genetika berdasarkan hasil dari pengujian Accuracy, Sensitifity, dan Precission. Berdasarkan nilai pengujian tersebut didapatkan algoritma yang terbaik untuk prediksi penyakit autoimun.

\section{Hasil dan Pembahasan}

\section{a. Implementasi Aplikasi Prediksi penyakit Autoimun}

Aplikasi prediksi penyakit autoimun dibangun menggunakan bahasa pemrograman PHP dan database MySQL. Pada Gambar 4 merupakan Form login berfungsi untuk memasukkan user dan password agar dapat menginputkan data ke system.

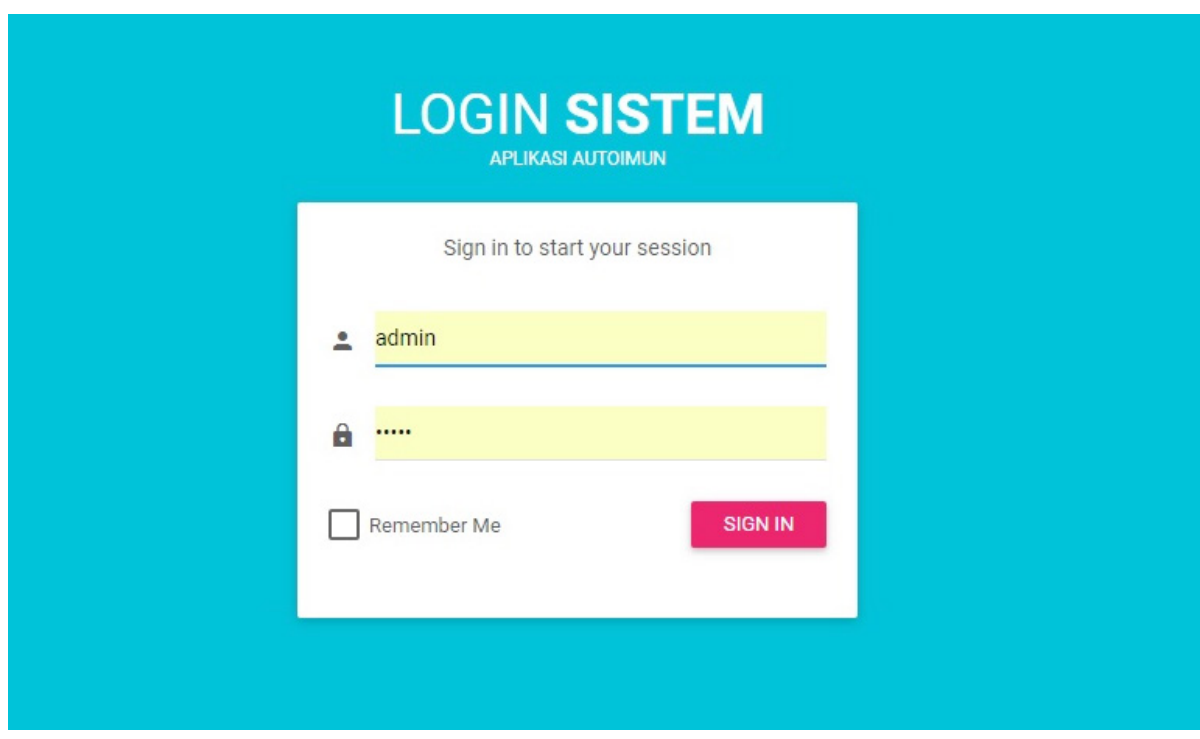

Gambar 4. Login sistem autoimun 


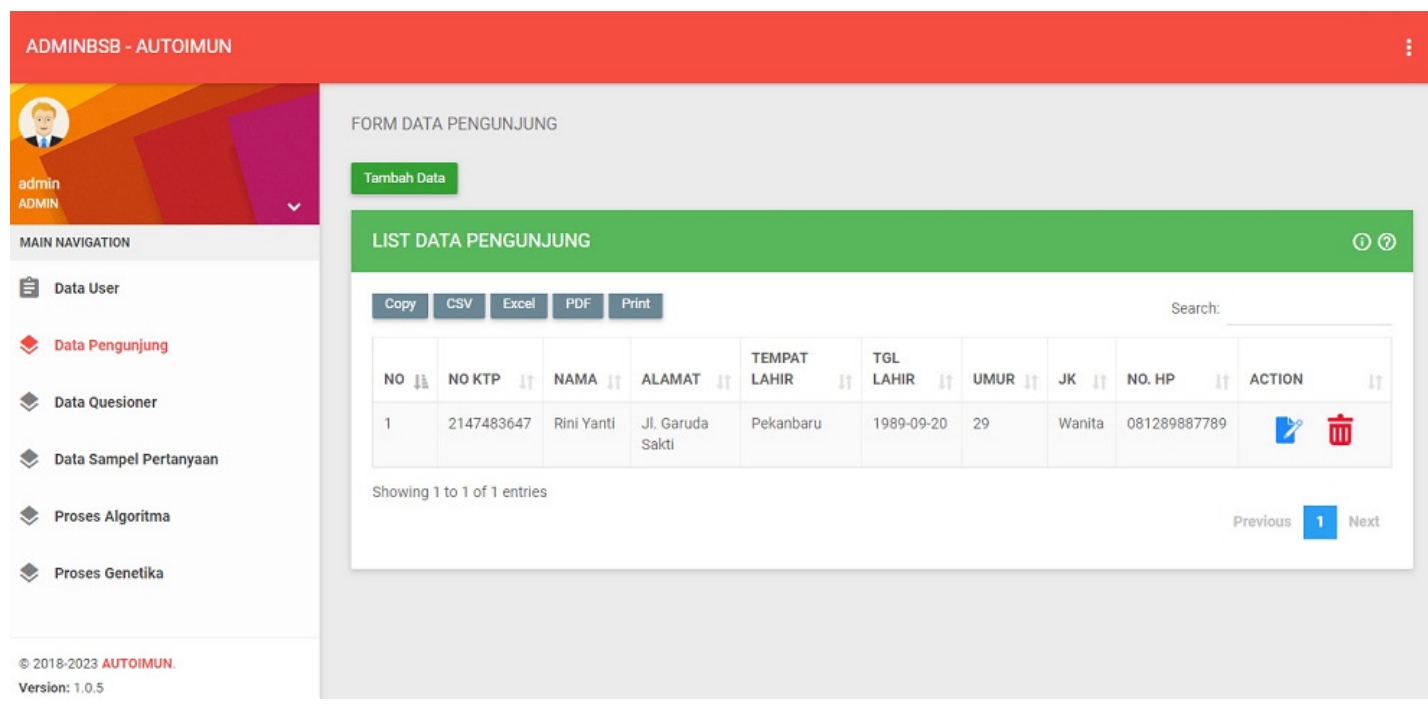

Gambar 5. List data pengunjung

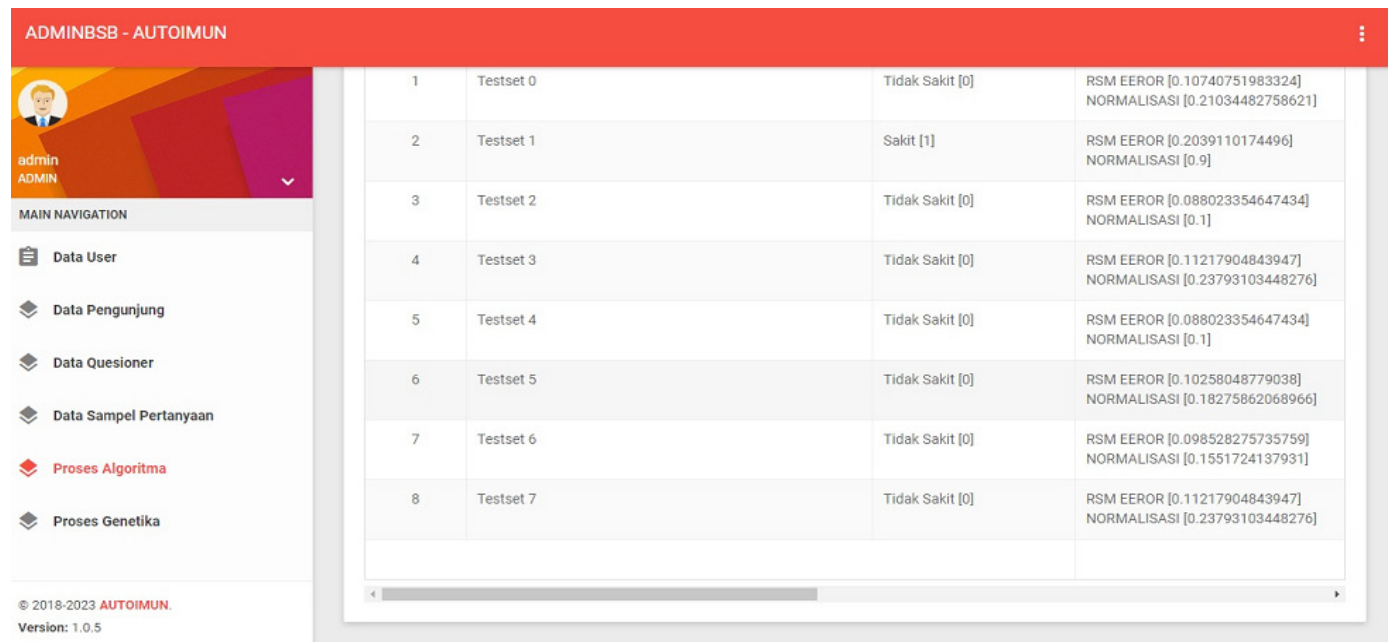

Gambar 6. Keputusan akhir dan nilai MSE algoritma backpropagation

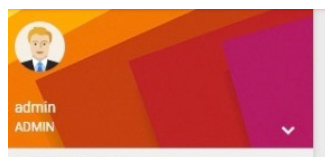

MAIN NAVIGATION

自 DataUser

$\approx$ Data Pengunjung

$\approx$ Data Quesioner

$\approx$ Data Sampel Pertanyaan

$\because$ Proses Algoritma

$\approx$ Proses Genetika

Q 2018-2023 AUTOIMUN.

Version: 1.0 .5

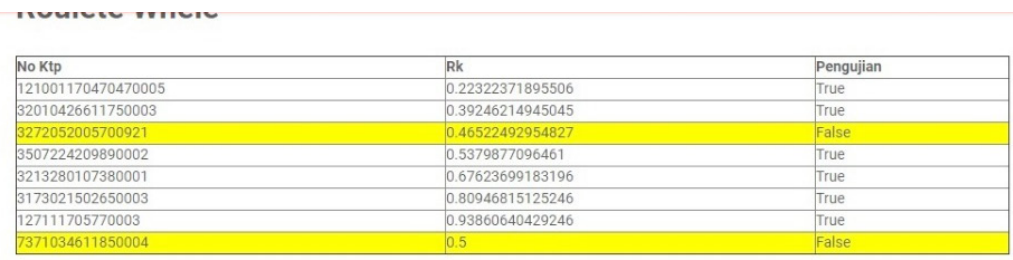

\section{Hasil Akhir}

\begin{tabular}{|l|l|l|}
\hline No Ktp & Rk & Rata-Rata Fungsi objektif \\
\hline 121001170470470005 & 0.22322371895506 & 29 \\
\hline 32010426611750003 & 0.39246214945045 & 54 \\
\hline 3272052005700921 & 0.46522492954827 & 25 \\
\hline 3507224209890002 & 0.5379877096461 & 30 \\
\hline 3213280107380001 & 0.67623699183196 & 25 \\
\hline 3173021502650003 & 0.8094681525256 & 28 \\
\hline 127111705770003 & 0.93860640429246 & 27 \\
\hline 7371034611850004 & 0.5 & 30 \\
\hline
\end{tabular}

Gambar 7. Hasil akhir algoritma genetika

Gambar 5 merupakan Form List Data Pengunjung digunakan untuk melihat biodata pengunjung yang mengisi questioner.

Gambar 6 merupakan Form Keputusan prediksi dari perhitungan algoritma backpropagation, proses hasil akhir dari metode yang digunakan untuk pengambilan keputusan dengan MSE 0.19, data Teset I, atau sampel dua, seperti gambar berikut:

Gambar 7 merupakan keputusan prediksi dari algoritma genetika, yang teridentifikasi penyakit autoimun adalah dengan RK 0.393, dengan rata-rata fungsi objektif 54. 
Hasil akhir pada proses prediksi yang didapat oleh algoritma genetika sama dengan prediksi yang dilakukan oleh metode backpropagation yaitu terdapat satu orang yang teridentifikasi penyakit autoimun, tapi terdapat perbedaan pada proses langkah kerja dan keakuratan dalam prediksi.

\section{b. Pengujian Accuracy, Sensitifity, dan Presicion}

Berdasarkan dari implementasi algoritma backpropagation dan algoritma genetika diperoleh nilai pengujian accuracy, sensitifity, dan Presicion sebagai berikut:

Tabel 3. Nilai pengujian algoritma

\begin{tabular}{ccc}
\hline Nilai & $\begin{array}{c}\text { Algoritma } \\
\text { Genetika }\end{array}$ & $\begin{array}{c}\text { Algoritma } \\
\text { Backpropagation }\end{array}$ \\
\hline Accuracy & 0.76 & 0.83 \\
Sensitifity & $81 \%$ & $97 \%$ \\
Presicion & $75 \%$ & $75 \%$ \\
\hline
\end{tabular}

c. Perbandingan Algoritma Backpropagation dan Algoritma Genetika

Berdasarkan tabel 3 yaitu pengujian algoritma, menyatakan bahwa accuracy algoritma backpropagation 0.83 dan nilai accuracy algoritma genetika 0.76. Tingkat akurasi dapat didiagnosis sebagai berikut [15]:

1) Akurasi $0.90-1.00=$ Excellent classification

2) Akurasi $0.80-0.90=$ Good classification

3) Akurasi $0.70-0.80=$ Fair classification

4) Akurasi $0.60-0.70=$ Poor classification

5) Akurasi $0.50-0.60=$ Failure

Nilai accuracy algoritma backpropagation berdasarkan tingkatan akurasi termasuk dalam klasifikasi good classification sedangkan algoritma genetika termasuk dalam kalsifikasi fair classification.

Nilai Sensitifity algoritma backpropagation 97\% dan algoritma genetika 81\%. Hasil tersebut menunjukkan bahwa nilai sensitifity algoritma backpropagation lebih tinggi dari algoritma genetika, dapat disimpulkan bahwa algoritma backpropagation dapat memprediksi penyakit autoimun dengan proporsi kasus positif yang terindentifikasi benar lebih banyak dari algoritma genetika.

Nilai Presicion algoritma backpropagation dan algoritma genetika memiliki angka yang sama yaitu $75 \%$.

\section{Kesimpulan}

Hasil perbandingan dari algoritma backpropagation dan algoritma genetika, menyimpulkan bahwa algoritma backpropagation lebih baik dalam melakukan prediksi penyakit autoimun dengan nilai akurasi 0.83 , sensitifity $97 \%$, dan precision $75 \%$.

\section{Persantunan}

Ucapan terima kasih kami sampaikan kepada Direktorat Riset dan Pengabdian Masyarakat Direktorat Jenderal Penguatan Riset dan Pengembangan Kementrian Riset, Teknologi, dan Pendidikan Tinggi atas pendanaan Penelitian Dosen Pemula (PDP) Tahun Pelaksanaan 2018.

\section{Daftar Pustaka}

[1] S. Waluyo, Penyakit-Penyakit Autoimun. Elek Media Komputindo, 2014

[2] PUSDATIN, Infodatin. Situasi Lupus di Indonesia. Pusat data dan Informasi Kementrian Kesehatan RI, 2017.

[3] E. Roviati, "Systemic Lupus Erithematosus (SLE): Kelainan Autoimun Bawaan yang Langka dan Mekanisme Molekulernya," Jurnal Sci. Educ., vol. 2:1, no. April, 2013.

[4] B. Rifai, "Algoritma Neural Network untuk Prediksi Penyakit Jantung," J. Techno Nusa Mandiri, vol. IX, no. 1, pp. 1-9, 2013.

[5] D. Kurnianingtyas, W. F. Mahmudy, and A. W. Widodo, "Optimasi Derajat Keanggotaan Fuzzy Tsukomoto Menggunakan Algoritma Genetika untuk Diagnosis Penyakit Sapi Potong," J. Teknologi Informasi dan Ilmu Komputer, vol. 4, no. 1, pp. 8-18, 2017.

[6] A. P. Windarto, M. R. Lubis, and L. R. Komprehensif, "Implementasi JST Pada Prediksi Total Laba Rugi Komprehensif Implementation of Neural Network in Predicting Total Comprehensive Income of Conventional Commercial Banks Using," J. Teknologi Informasi dan Ilmu Komputer, vol. 5, no. 4, pp. 411-418, 2018.

[7] I. Putri and F. Nhita, "Analisis dan Implementasi Algoritma Genetika (Ag) pada Jaringan Syaraf Tiruan (Jst) untuk Prediksi Curah Hujan di Kabupaten Bandung". Skripsi. Universitas Telkom. Bandung. 2014.

[8] M. S. Ali and M. N. I. Mondal, "Character Recogntion System: Performance Comparison of Neural Networks and Genetic Algorithm," 1st Int. Conf. Comput. Inf. Eng. ICCIE 2015, pp. 91-94, 2016.

[9] M.-C. Lee and C. To, "Comparison of Support Vector Machine and Back Propagation Neural Network in Evaluating the Enterprise Financial Distress," Int. J. Artif. Intell. Appl., vol. 1, no. 3, pp. 31-43, 2010

[10] L. R. Dorteus and K. L. Ferry, "Analisis dan Prediksi Penyakit Jantung Koroner di Kota Ambon Menggunakan Jaringan Saraf Tiruan," J. Imu Mtematika dan Terap., vol. 10, no. 2, pp. 97105, 2016.

[11] V. Pebrianasari, E. Mulyanto, and D. Erlin, "Analisis Pengenalan Motif Batik Pekalongan Menggunakan Algoritma Backpropagation," Techno.COM, vol. 14, no. 4, pp. 281-290, 2015.

[12] I. Ispandi and R. Wahono, "Penerapan Algoritma Genetika untuk Optimasi Parameter pada Support Vector Machine untuk Meningkatkan Prediksi Pemasaran Langsung," J. Intell. Syst., vol. 1, no. 2, pp. 115-119, 2015.

[13] Y. I. Kurniawan, "Perbandingan Algoritma Naive Bayes dan C.45 Dalam Klasifikasi Data Mining," J. Teknol. Inf. dan Ilmu Komput., vol. 5, no. 4, pp. 
455-464, 2018.

[14] T. Vafeiadis, K. I. Diamantaras, G. Sarigiannidis, and K. C. Chatzisavvas, "A comparison of Machine Learning Techniques for Customer Churn Prediction," Simul. Model. Pract. Theory, vol. 55, no. June, pp. 1-9, 2015.
[15] M. Badrul, "Optimasi Algoritma Neural Network Dengan Algoritma Genetika dan Particle Swarm Optimization untuk Memprediksi Hasil Pemilukada," J. Pilar Nusa Mandiri, vol. 13, no. 1, pp. 1-11, 2017. 